with the proposed structures of the fatty acid moieties of the sterol esters.

The results so far obtained in this work leave little doubt that the major sterol ester of $E$. floridana reared on diet 1 is cholesteryl oleate. The remaining sterol esters appear to consist principally of linoleate and a small saturated ester fraction in which palmitate is the principal component. Further work is in progress to determine whether there is any consistent infiuence of the diet on the proportions of the various cholesterol esters in this insect.

We thank Prof. Konrad Bloch, in whose laboratory this work was carried out, for his continued interest and encouragement. One of us (R. B. C.) is an established investigator of the American Heart Association. This work was supported by grants from the Amorican Heart Association and the U.S. National Institutes of Health.

M. L. BADE

R. B. Clayton

Conant Chemical Laboratories,

Harvard University,

Cambridge, Mass.

'Casida, J. E., Beck, S. D., and Cole, M. J., J. Biol. Chem., 224, 365 (1957).

${ }^{2}$ Clayton, R. B., and Edwards, A. M., Biochem. Biophys. Res. Comm., 6, 281 (1961).

'Robbins, W. E., Kaplanis, J. N., Monroe, R. E., and Tabor, L. A., Ann. Ent. Soc. Amer., 54, 165 (1961).

4 Clayton, R. B., Nature, 184, 1166 (1959).

${ }^{5}$ Noland, J. X., and Baumann, C. A., Proc. Soc. Exp. Biol. and Med., 70, 198 (1949).

Barron, E. J., and Hanahan, D. J., J. Biol. Chem., 231, 493 (1958).

'Klein, P. D., and Janssen, E. T., J. Biol. Chem., 234, 1417 (1959).

'Clayton, R. B., Biochem., 1, 357 (1962).

Bade, M. L., and Clayton, R. B. (in preparation).

${ }^{10}$ Lennarz, W. J., Scheuerbrandt, G., and Bloch, K., J. Biol. Chem., 287, $664(1962)$.

${ }^{21}$ Scheuerbrandt, G., and Bloch, K., J. Biol. Chem., 237, 2064 (1962).

\section{Phospholipid Composition and Turnover in Rat Intestinal Mucosa during Fat Absorption}

SINCLAIR ${ }^{1}$ suggested in 1929 that phospholipids are obligatory intermediates in the absorption of fat. Later work by Zilversmit, Entenman and Chaikoff ${ }^{2}$ indicated, however, that there is little or no increase in turnover of the gross phospholipid fraction during absorption. Johnston and Bearden ${ }^{3}$ recently obtained evidence that a minor component, phosphatidic acid, has increased turnover during fat absorption in vitro. It seemed important, therefore, to examine the turnover of individual mucosal phospholipids during fat absorption in vivo, with special reference to phosphatidic acid.

Rats, previously starved for periods of about $15 \mathrm{~h}$, were fed with $0.75 \mathrm{ml}$. of olive oil, by stomach tube. A period of $2 \mathrm{~h}$ was allowed for absorption to proceed and the animals were then injected intravenously with $1 \mathrm{mc}$. carrier-free $\mathrm{NaH}_{2}{ }^{32} \mathrm{PO}_{4}$ in $1 \mathrm{ml}$. of 0.9 per cent sodium chloride. Half an hour after the injection of the isotope, the animals were killed, the intestine removed and the contents of the small intestine, stomach and cecum irrigated with 0.9 per cent sodium chloride. The excess fat was extracted from these washings and related to the amount fed. The mucosal cells were then scraped off and immediately homogenized in ice-cold 10 per cent trichloroacetic acid solution. Phospholipids extracted from the precipitated material were subjected to mild alkaline hydrolysis and the watersoluble phosphate esters were separated by two-dimensional paper chromatography ${ }^{4}$. The presence of phosphatidie acid was confirmed by silicic acid chromatography. The phosphatidic acid-containing fraction was then hydrolysed by mild alkali and the resulting phosphate esters separated by ion-exchange chromatography ${ }^{5}$ Specific activities were calculated for each phospholipid and related to the specific activity of the acid-soluble phosphate fraction. All results were related to results from animals fed with $0.75 \mathrm{ml}$. of a 25 per cent glucose solution, but treated in the same way in all other respects.

The chromatograms showed a phospholipid pattern similar to that seen in liver, but the amount of inositol phospholipid was low. Phosphatidic acid was present in small amounts (approximately 2 per cent of the total lipid phosphorus) but had a higher specific activity than any other lipid; this did not appear to change during fat absorption. The high turnover of phosphatidylinositol in both control and fat-fed animals is noteworthy. The specific activity of the gross phospholipid fraction increased slightly during fat absorption, confirming the studies of Zilversmit et al. ${ }^{2}$. This increase appeared to be due chiefly to a more rapid turnover of phosphatidylcholine. The results are summariz ed in Table 1.

Table 1. Relative Specific Activities of Rat Mucosal Phospholipidos Phospholipid

Phosphatidylcholine

Phosphatidylethanolamine

Phosphatidylserine $\ddagger$

Phosphatidylinositol

Diphosphatidylgly

Total phospholipid fraction

Control rats $\dagger \quad$ Fat-fed rats $\dagger$ * Expressed as: $\frac{\text { counts per } 100 \text { sec per } 100 \mu \mathrm{g} \text { lipid } \mathrm{P} \times 10^{\mathrm{s}}}{\text { counts per } 100 \mathrm{sec} \text { per } 100 \mu \mathrm{g} \text { acid-soluble } \mathrm{P}}$

$\dagger$ Average values, number of rats in parentheses.

\$ Since both counts and $P$ content were very low, the difference between control and fat-fed rats is probably not significant.

The increased turnover of phosphatidylcholine during fat absorption may be connected with its requirement in stabilizing chylomicrons. The failure to find an increased specific activity of phosphatidic acid during fat absorption appears to conflict with the results of Johnston and Bearden $^{3}$. There are, however, several important differences in experimental conditions since they studied hamster intestine in vitro, absorbing fatty acid rather than partially hydrolysed triglycerides. Phosphatidic acid is an intermediate in triglyceride biosynthesis when $\mathrm{L}$-3-glycerophosphate is the glycerol precursor, but the resynthesis of triglyceride can also take place with monoglyceride as glycerol precursor ${ }^{6}$. This latter pathway, which does not involve phosphatidic acid, could well be more important when triglyceride is fed than when fatty acid is given, since lipolysis would provide monoglyceride.

M. I. GURR

W. F. R. Pover

J. N. HaWTHORNE

A. C. Frazer

Department of Medical Biochemistry and Pharmacology, Medical School, Birmingham, 15.

${ }^{2}$ Sinclair, R. G., J. Biol. Chem., 82, 117 (1929).

2 Zilversmit, D. B., Entenman, C., and Chaikoff, I. I., J. Biol. Chem., 172 637 (1948).

${ }^{3}$ Johnston, J. M., and Bearden, J. H., Arch. Biochem. Biophys., 90, 57 (1960).

4 Dawson, R. M. C., Biochem. J., 75, 45 (1960)

${ }^{5}$ Hübscher, G., Kemp, P., and Hawthorne, J. N., J. Lipid Res., 1, 433 (1960).

${ }^{6}$ Clark, B., and Hübscher, G., Biochim. Biophys. Acta, 46, 479 (1961).

\section{PHYSIOLOGY}

\section{Participation of Hepatic Glucoreceptors in the Control of Intake of Food}

Is a previous communication ${ }^{1}$, it was shown that anorexia produced by adrenaline is easily conditioned, while anorexia produced by the injection of glucose, instead of becoming conditioned, disappears with repetition. It was also observed during this work that intraperitoneal injection of glucose had a stronger and more persistent anorectic effect than intravenous.

After intraperitoneal injections of glucose $(300 \mathrm{mg} / \mathrm{kg}$ ) the venous and arterial glycæmias started to fall, reaching a minimum of $5-20 \mathrm{mg} / 100 \mathrm{ml}$. under the basal 3 min after 